\title{
IgG3 cryoglobulins in autoimmune MRL-lpr/lpr mice: immunopathogenesis, therapeutic approaches and relevance to similar human diseases
}

\author{
Shozo Izui, Thierry Berney, Takanori Shibata, Thierry Fulpius
}

\begin{abstract}
MRL-lpr/lpr mice spontaneously develop an autoimmune disease resembling systemic lupus erythematosus and rheumatoid arthritis. One of the unique serological abnormalities in this strain is remarkably high concentrations of cryoglobulins. Analysis of immunoglobulin components in their cryoglobulins has shown selective enrichment of a particular IgG subclass, IgG3. As IgG3 enrichment is also found in two other cryoglobulins, which are induced after injection with bacterial lipopolysaccharides or infection with malaria, IgG3 apparently represents a major source of murine cryoglobulins. Studies on murine IgG3 monoclonal antibodies (mAbs) have clearly shown that murine IgG3 have the unique physicochemical property to self associate through non-specific IgG3 Fc-Fc interaction, and that most of them can generate monoclonal cryoglobulins. Most strikingly, IgG3 monoclonal cryoglobulins with rheumatoid factor (RF) activity induce extensive pathological manifestations: skin vascular purpura and glomerulonephritis with 'wire loop' lesions. Although the cryoglobulin activity of IgG3 RF mAb is solely responsible for the generation of glomerular lesions (both RF and cryoglobulin activities are necessary for skin vascular lesions), the absence of nephritogenic activity by some IgG3 cryoglobulins supports the idea that qualitative features of cryoglobulins are critical to determine their pathogenic activity. The demonstration of a positive correlation between the production of IgG3 cryoglobulins and the development of lupus nephritis in MRL-lpr/lpr mice further substantiates the pathological importance of cryogenic autoantibodies. On the other hand, it should be emphasised that non-cryogenerating IgG3 autoantibodies may not be harmful, but even protective, as a result of their interaction with pathogenic IgG3 cryoglobulins. Finally, the development of an experimental model of cryoglobulinaemia associated with vascular and glomerular disease certainly represents an invaluable opportunity to study the molecular mechanisms responsible for the
\end{abstract}

generation of cryoglobulins and their associated tissue lesions, and also to assess various therapeutic approaches. Our demonstration that anti-idiotypic $\mathbf{m A b}$ can prevent the pathogenic effects of the cryoprecipitable IgG3 RF mAb suggests strongly that such a therapeutic approach might be successful in similar diseases in man.

\section{(Ann Rheum Dis 1993; 52: S48-S54)}

Cryoglobulins are immunoglobulins which precipitate at temperatures lower than $37^{\circ} \mathrm{C}$ with resolution upon warming. ${ }^{1-3}$ Since their initial characterisation by Lerner et $a l^{1}$ it has been recognised that they are not a single distinct group of immunoglobulins but have heterogeneous composition and physical properties. Cryoglobulins can be classified into three types ${ }^{3}$ according to the presence in the cryoprecipitate of monoclonal immunoglobulins (type I), both monoclonal and polyclonal immunoglobulins (type II), or polyclonal immunoglobulins with or withou other serum proteins or exogenous antigens (type III). Monoclonal type I cryoglobulins are mostly associated with various lymphoproliferative disorders. Mixed type II or type III cryoglobulins are often found in serum from patients with autoimmune diseases, such as systemic lupus erythematosus (SLE) and rheumatoid arthritis, or with a variety of chronic infectious diseases.

Clearly, the interaction between immunoglobulin molecules plays a critical part in the formation of cryoglobulins as the sole or major components of a vast majority of cryoglobulins are immunoglobulins. The demonstration of rheumatoid factor (RF) activity or antiidiotypic-like activity, or both, in IgM present in mixed cryoglobulins suggests the involvement of immune mechanisms in the generation of mixed cryoglobulins.$^{2-6}$ However, one should be cautious about the fact that mixed cryoglobulins can be generated after in vitro, but not in vivo, interaction of low affinity IgM RF with IgG complexes during the incubation of serum samples in test tubes at $4^{\circ} \mathrm{C}$ to isolate cryoglobulins. The molecular mechanisms responsible for the generation of type I monoclonal cryoglobulins are less clear. Available data suggest that several different 
Table 1 Selective concentration of IgG3 in three different sources of murine cryoglobulins

\begin{tabular}{lllllll}
\hline Cryoglobulins $^{\star}$ & \multicolumn{7}{l}{ Cryoglobulins v serum $\dagger$} \\
\cline { 2 - 6 } & $\operatorname{IgM}(\%)$ & $\operatorname{IgG1}(\%)$ & $\operatorname{IgG2a}(\%)$ & $\operatorname{Ig} G 2 b(\%)$ & $\operatorname{IgG3(\% )}$ \\
\hline MRL-lpr/lpr & $<1$ & $<1$ & $<1$ & $<1$ & 10 \\
Lipopolysaccharide induced & 2 & $<1$ & $<1$ & $<1$ & 15 \\
Malaria induced & 1 & $<1$ & $<1$ & $<1$ & 8 \\
\hline
\end{tabular}

*MRL-lpr/lpr: 4 months of age. Lipopolysaccharide induced: 15 days after the injection of 50 $\mu \mathrm{g}$ of Salmonella minnesota R595 LPS in BALB/c mice. Malaria-induced: 12 days after the injection of malaria in BALB/c mice.

†Cryoglobulin concentration of each immunoglobulin (Ig) isotype is expressed as a percentage of their serum concentration by the following formula:

$\times 100(\%)$ lpr/lpr mice are composed almost exclusively of IgG of polyclonal origin, the striking observation is that they are markedly enriched in IgG3, as compared with other IgG subclasses (table 1). This preferential precipitation of IgG3 in polyclonal cryoglobulins is not seen exclusively in autoimmune MRL-lpr/lpr mice but can also be found in non-autoimmune mice after polyclonal stimulation of B cells with bacterial lipopolysaccharides or infection with malaria parasites. ${ }^{14}$ The absence of specific concentrations of anti-lipopolysaccharide, anti-malaria, or anti-DNA antibodies in each model of cryoglobulinaemia excludes a possible involvement of idiotype-anti-idiotype interaction in the generation of these cryoglobulins.

As IgG3 are selectively concentrated in spontaneous and induced cryoglobulins it is likely that the self association and subsequent cryoprecipitation of murine IgG3 molecules is the principal mechanism responsible for the generation of cryoglobulins in mice. To consider this question we used IgG3 monoclonal antibodies (mAbs) from autoimmune MRL-lpr/lpr and $(\mathrm{NZB} \times \mathrm{NZW}) \mathrm{F}_{1}$ mice to assess their ability to generate cryoglobulins. Twenty eight of $32 \mathrm{mAbs}$, independently of their immunological specificities, generated cryoglobulins, each composed exclusively of IgG3 mAb without the involvement of any other antigens. ${ }^{141617}$ The cryoglobulin activity of IgG3 is not a phenomenon unique to autoimmune mice, because five of eight IgG3 anti-dinitrophenyl mAbs derived from nonautoimmune mice similarly develop cryoglobulins. ${ }^{18}$ Such an activity of IgG3 mAb has also been noted by others. ${ }^{19-21}$ The role of the $\gamma 3$ constant $(\mathrm{C} \gamma 3)$ region for the cryoglobulin generation has been most directly demonstrated by immunoglobulin class switch variant experiments: the cryoglobulin activity is gained after the immunoglobulin class switch of $\mathrm{mAb}$ from IgM to IgG3, but lost after the class switch from IgG3 to IgG1.14 $2021 \mathrm{a}$

All these data clearly indicate that murine IgG3 have a unique physicochemical property which allows them to self associate through non-immunological $\gamma 3 \mathrm{Fc}-\mathrm{Fc}_{\mathrm{c}}$ interaction, and that most of them can generate monoclonal cryoglobulins, independently of their specificities and origins. This unique property of murine IgG3 to self associate is, however, not limited to cryoprecipitating mAbs. In fact, both cryoprecipitating and non-cryoprecipitating IgG3 mAbs can interact with each other, in a quantitatively similar manner, but not with other IgG subclasses. ${ }^{14} 1822$ These non-specific IgG3-IgG3 interactions would account for the microaggregate formation noted in the first described murine IgG3 myeloma protein J606. ${ }^{23}$ The complete identity of the nucleotide sequences of the $\mathrm{C} \gamma 3$ regions of the noncryoprecipitable J606 protein and a cryoprecipitable IgG3 mAb (clone 6-19) derived from MRL-lpr/lpr mice ${ }^{24}$ rules out an abnormality in the $\mathrm{C} \gamma 3$ region of either cryoprecipitable or non-cryoprecipitable IgG3 proteins. Thus, clearly, the $\mathrm{C} \gamma 3$ domain is necessary for the self association of IgG3 mAb parallel, they produce the most remarkable amounts of cryoglobulins among several SLEprone mice, such as $(\mathrm{NZB} \times \mathrm{NZW}) \mathrm{F}_{1}$ or $\mathrm{BXSB}$ mice. ${ }^{13}{ }^{14}$ Although cryoglobulins from MRL- 
but not sufficient in itself to determine cryoprecipitation. Apparently, an additional factor is required to form the cryoglobulin. In this regard it should be noted that the cryoprecipitation of anti-dinitrophenyl IgG3 $\mathrm{mAb}$ is completely inhibited after the binding of monomeric anionic dinitrophenyl-amino acid conjugates and can be enhanced by the binding of cationic conjugates. ${ }^{18}$ This is consistent with the idea that electrostatic interactions are a significant factor in the precipitation process, as suggested by studies on human monoclonal cryoglobulins. ${ }^{7825}$ It is not surprising that the determination of the isoelectric point of human monoclonal cryoglobulins $^{78}$ and murine IgG3 cryoglobulins ${ }^{18}$ failed to show differences between cryoimmunoglobulins and non-cryoimmunoglobulins, even if such differences exist, because the presence of only a few electrostatic contacts may be all that is necessary to produce abnormal solubility properties. Therefore, it is likely that the physicochemical behaviour of the $\mathrm{C} \gamma 3$ region is related to the self associating property of the IgG3 molecule, but that the presence of certain clusters of charged domains in its Fab portion determines its cryoglobulin activity.

The molecular basis for the peculiar self associating activity of murine IgG3 remains unclear. One attractive hypothesis suggests a role for a carbohydrate side chain attached to the immunoglobulin. In fact, the presence of a carbohydrate side chain on the $\mathrm{V}_{\mathrm{H}}$ region of a cryoprecipitating human monoclonal IgG has been shown to contribute to its cold insolubility. ${ }^{26}$ Furthermore, the glycosylation of some proteins has been shown to decrease their solubility as a result of the formation of new intermolecular contacts. ${ }^{27}$ In this regard it is particularly interesting to note the demonstration of a unique $\mathrm{N}$-linked glycosylation site in the $\mathrm{CH} 3$ domain of murine IgG3, which is absent in other IgG isotypes. $^{28}$ Possibly, the presence of the

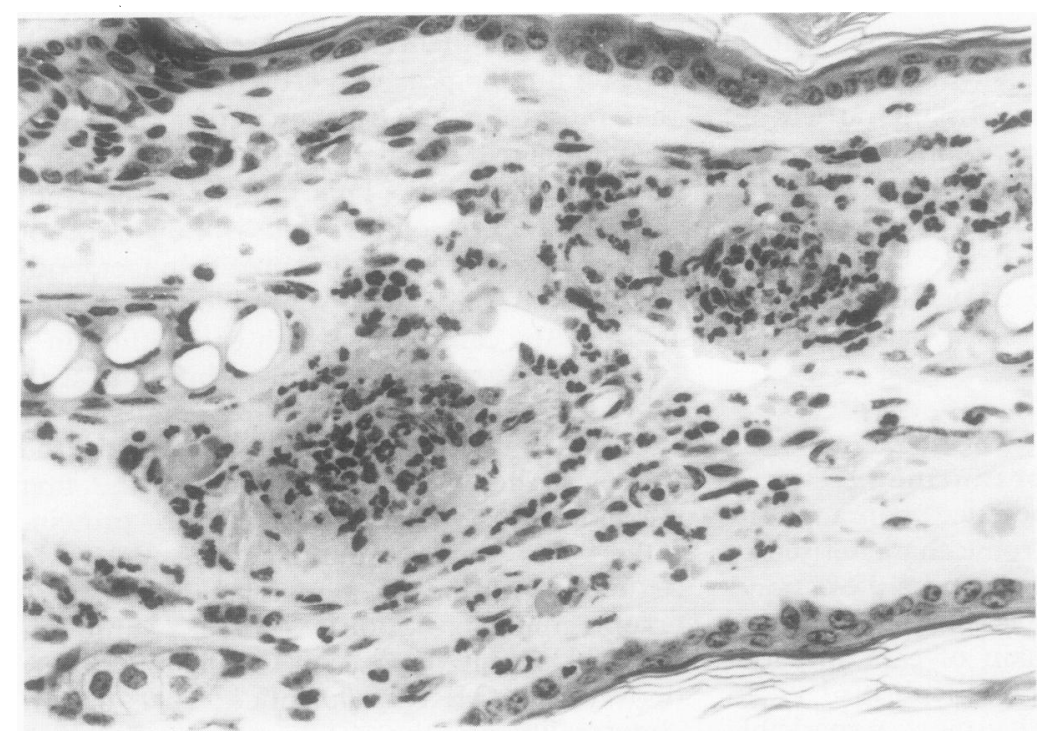

Figure 1 Representative histological appearance of skin lesions after the intraperitoneal injection of 6-19 IgG3 rheumatoid factor hybridoma cells. Leucocytoclastic vasculitis is characterised by the infiltration of polymorphonuclear leucocytes and the extravasation of erythrocytes. carbohydrate side chain may produce additional electrostatic contacts between the charged sialic acid residues and a positively charged residue(s) present in the $\operatorname{IgG} 3$ molecules, or the $\mathrm{C} \gamma 3$ region may have a lectin-like sequence that interacts with the carbohydrate chain present in the $\mathrm{CH} 3$ domain. An alternative hypothesis is that there may exist, in the $\mathrm{C} \gamma 3$ region, complementary amino acid sequences responsible for IgG3 self association, similar to these described for $\mathrm{T} 15$ self binding antibodies. ${ }^{29}$

\section{Induction of cryoglobulin associated tissue lesions by IgG3 cryoglobulin mAbs} As most IgG3 mAbs, independently of their specificities, form cryoglobulins, we explored whether cryoprecipitable IgG3 mAbs can provoke tissue lesions in normal mice after intraperitoneal injection of hybridomas which secrete IgG3. One of the monoclonal IgG3 RFs specific for IgG2a, clone 6-19, induced the most remarkable disease. ${ }^{16}$ Five to seven days after the injection of 6-19 IgG3 RF hybridoma into normal mice, vascular purpura, which is the most common manifestation in patients with cryoglobulinaemia, ${ }^{3}$ developed in the skin of the ears, tails, and foot pads, which are not well protected by hair from thermic variations. Histological examination of the skin lesions showed an intracapillary precipitation of cryoglobulins associated with an extensive infiltration of polymorphonuclear leucocytes around the vessels and into the subcutaneous tissue, and a massive extravasation of erythrocytes (fig 1). Moreover, the 6-19 mAb induced a severe acute glomerulonephritis (fig 2). At the initial phase, predominant glomerular lesions were characterised by exudation of polymorphonuclear leucocytes and a mild increase in glomerular cellularity. Then a progressive accumulation of cryoglobulins in the subendothelial spaces of glomerular capillary walls led to the formation of glomerular lesions resembling the 'wire loop' lesion, ${ }^{17}$ characteristically described for lupus nephritis. In a further advanced case a disseminated plugging of glomerular capillaries by voluminous cryoglobulins, often obstructing the capillary lumen, was noted. The generation of wire loop lesions by the 6-19 $\mathrm{RF} \mathrm{mAb}$ in immunoglobulin deficient mice ${ }^{30}$ supports the idea that the direct localisation of 6-19 monoclonal cryoglobulins without the involvement of immune complex formation is responsible for the development of such lesions.

As the 6-19 mAb has both anti-IgG2a RF and cryoglobulin activities, it is important to determine the role of each activity in the pathogenicity of the 6-19 mAb. To answer this question we produced a 6-19-J558 hybrid antibody, composed of 6-19 $\gamma 3$ heavy chains and J558 $\lambda 1$ light chains, which retained the cryoglobulin activity, but had lost the antiIgG2a RF activity. ${ }^{30}$ Mice injected with this hybrid antibody developed glomerular lesions as severe as those induced by the $6-19 \mathrm{mAb}$, but completely failed to develop skin vascular 
lesions (table 2). This strongly suggests that different pathological mechanisms govern the development of each tissue lesion: both RF and cryoglobulin activities are required to induce cutaneous vascular lesions, whereas the cryoglobulin activity alone is sufficient to cause glomerular lesions. This conclusion is further supported by the fact that the depletion of the corresponding autoantigen, IgG2a, in mice by treatment with antibodies to IgM from birth also prevents the development of skin but not glomerular lesions after injection of 6-19

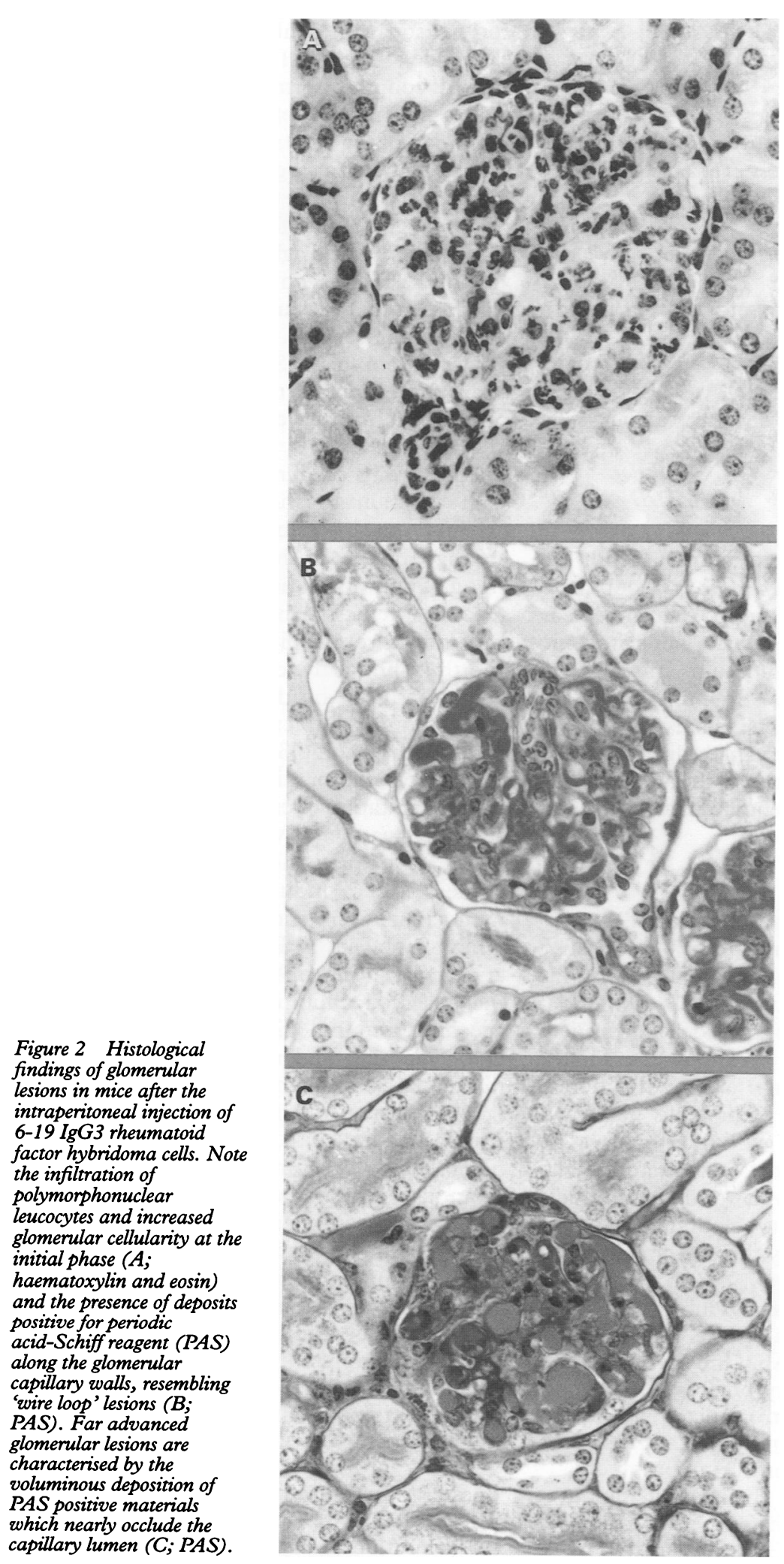

Table 2 Pathogenic activity of 6-19 $m A b^{\star}$ and its variants

\begin{tabular}{|c|c|c|c|c|c|}
\hline \multirow[t]{2}{*}{$m A b$} & \multirow[t]{2}{*}{ Isotype } & \multicolumn{2}{|c|}{ Activities } & \multicolumn{2}{|c|}{ Lesions } \\
\hline & & $R F^{\star}$ & Cryoglobulin & Skin & Kidney \\
\hline $\begin{array}{l}6-19 \\
6-19\end{array}$ & $\begin{array}{l}\text { IgG3 } \\
\text { IgG1 }\end{array}$ & + & \pm & + & \pm \\
\hline $6-19-J 558 \lambda 1$ & IgG3 & - & + & - & + \\
\hline
\end{tabular}

${ }^{\star} \mathrm{mAb}=$ monoclonal antibody; $\mathrm{RF}=$ rheumatoid factor.

mAb. ${ }^{30}$ The involvement of RF, possibly subsequent immune complex formation and complement activation, in the generation of cryoglobulin associated skin vascular lesions would explain the fact that none of the non-RF IgG3 monoclonal cryoglobulins, including anti-DNA mAbs, induce skin lesions, probably because insufficient amounts of the corresponding autoantigens are present in the circulating blood of non-autoimmune mice to form immune complexes. In addition, we have noted that an IgG1 class switch variant of IgG3 6-19 mAb, which loses the cryoglobulin activity, fails to generate both skin and glomerular lesions (table 2). ${ }^{21 a}$ This indicates that the cryoprecipitating activity of IgG3 RF $\mathrm{mAb}$ plays a crucial part in the development of skin vasculitis and glomerulonephritis induced by IgG3 RF mAb. This is consistent with our recent finding that among a panel of antiIgG2a RF mAbs of different immunoglobulin isotypes, only the RF mAbs able to cryoprecipitate-all from the IgG3 subclasscan induce skin and glomerular lesions. ${ }^{24}$ In addition, the fact that the pathogenicity of autoantibodies is dramatically influenced by the immunoglobulin constant region supports the importance of subpopulation(s) of autoantibodies in the pathogenesis of autoantibody mediated tissue lesions.

It should be emphasised that certain IgG3 cryoglobulin mAbs cause only minimal glomerular changes, ${ }^{16}{ }^{17} 21$ though their serum concentrations of cryoglobulins are comparable or even higher than those of mice injected with pathogenic IgG3 mAb (table 3). This would well explain the fact that the quantity of circulating cryoglobulins does not always correlate with the degree of nephropathy in patients with cryoglobulinaemia. ${ }^{31}$ This suggests that qualitative features of cryoglobulins are critical in the nephritogenic activity of IgG3 cryoglobulins. As there is no mutation in the $\mathrm{C}_{\gamma 3}$ region of the most pathogenic 6-19 $\mathrm{mAb},{ }^{24}$ one may postulate that a unique sequence present in the $V$ regions may determine the nephritogenic activity of IgG3 cryoglobulins. In this context it should be repeated that the electrostatic charges in the $\mathrm{V}$ regions can markedly influence the cryoglobulin activity of IgG3. ${ }^{18}$ Accordingly, the acquisition or loss of charged amino acid residues as a result of somatic mutations in autoantibodies during the course of autoimmune responses, as reported in the case of antibodies to DNA in MRL-lpr/lpr mice, ${ }^{32}$ may create more pathogenic cryogenerating autoantibodies. Alternatively, possible differences in the structure of carbohydrate side chains present in the $\mathrm{CH} 3$ domain of $\mathrm{IgG} 3$ 
Table 3 Mean (SD) serum IgG3 and cryoglobulin concentrations, and development of skin and glomerular lesions in mice injected with various IgG3 hybridoma cells

\begin{tabular}{|c|c|c|c|c|c|}
\hline \multirow[t]{2}{*}{$m A b^{*}$} & \multirow[t]{2}{*}{ Specificity } & \multicolumn{2}{|l|}{ Serum $\dagger$} & \multicolumn{2}{|c|}{ Lesions } \\
\hline & & $\begin{array}{l}\mathrm{IgG3} \\
(\mathrm{mg} / \mathrm{ml})\end{array}$ & $\begin{array}{l}\text { Cryoglobulin } \\
(\mu \mathrm{g} / \mathrm{ml})\end{array}$ & Skin & Kidney \\
\hline $\begin{array}{l}6-19 \\
\text { AM16 } \\
5-7 B \\
1-10 B 4\end{array}$ & $\begin{array}{l}\text { RF } \\
\text { RF } \\
\text { RF } \\
\text { RF }\end{array}$ & $\begin{array}{r}3 \cdot 3(0 \cdot 6) \\
1 \cdot 8(0 \cdot 6) \\
6 \cdot 1(1 \cdot 7) \\
12 \cdot 0(3 \cdot 8)\end{array}$ & $\begin{array}{l}43(17) \\
14(3) \\
29(10) \\
55(31)\end{array}$ & $\begin{array}{l}+ \\
+ \\
+ \\
+\end{array}$ & $\begin{array}{l}+ \\
+ \\
+ \\
+\end{array}$ \\
\hline $\begin{array}{l}\text { SH-11 } \\
9-20 \\
9-83\end{array}$ & $\begin{array}{l}\text { Anti-DNA } \\
? \\
?\end{array}$ & $\begin{array}{l}2 \cdot 2(1.0) \\
5.4(1.3) \\
2 \cdot 9(0.8)\end{array}$ & $\begin{array}{c}6(2) \\
534(60) \\
31(7)\end{array}$ & $\begin{array}{l}- \\
- \\
-\end{array}$ & $\begin{array}{l}+ \\
+ \\
+\end{array}$ \\
\hline $\begin{array}{l}2-2 G \\
9-44\end{array}$ & ? & $\begin{array}{l}32 \cdot 0(6 \cdot 4) \\
14 \cdot 8(4 \cdot 4)\end{array}$ & $\begin{array}{c}1560(760) \\
660(70)\end{array}$ & $\begin{array}{l}- \\
-\end{array}$ & - \\
\hline
\end{tabular}

${ }^{\star}$ Hybridoma cells $\left(10^{7}\right)$ were injected intraperitoneally into normal mice. 6-19, AM16, 5-7B, and 1-10B4 are anti-IgG2a RF mAbs derived from MRL-lpr/lpr mice, ${ }^{16}{ }^{24} \mathrm{SH}-11$ is an anti-DNA mAb from $(\mathrm{NZB} \times \mathrm{NZW}) \mathrm{F}_{1}$ hybrid mice, ${ }^{17}$ and the specificities of the other mAbs are unknown. f Serum concentrations of $\mathrm{IgG} 3(\mathrm{mg} / \mathrm{ml})$ and cryoglobulins $(\mu \mathrm{g} / \mathrm{ml})$ at death.

Table 4 Inhibition of 6-19 rheumatoid factor monoclonal antibody $(\mathrm{mAb})$ induced tissue lesions by anti-idiotypic 6-19mAb

\begin{tabular}{lccr}
\hline Pretreatment $^{*}$ & Serum $\dagger$ & Lesions \\
\cline { 2 - 3 } & $\begin{array}{l}I g G 3 \\
(\mathrm{mg} / \mathrm{ml})\end{array}$ & $\begin{array}{l}\text { Cryoglobulin } \\
(\mathrm{mg} / \mathrm{ml})\end{array}$ & \\
\hline Anti-idiotype & $3.4(0 \cdot 5)$ & $<0.1$ & $0 / 20$ \\
Control & $15.3(1 \cdot 1)$ & $1.6(0 \cdot 2)$ & $20 / 20$
\end{tabular}

$\star 20 \mathrm{mg}$ of anti-6-19 idiotypic or control mAbs was injected intraperitoneally to $\mathrm{BALB} / \mathrm{c}$ mice six hours before intraperitoneal injection of $20 \mathrm{mg}$ of $6-19 \mathrm{mAb}$. Mice were killed 18 hours after the $6-19 \mathrm{mAb}$ injection.

tMean (SD) serum concentrations of IgG3 and cryoglobulins $(\mathrm{mg} / \mathrm{ml})$ were determined at death.

antibodies may have a determining role for the nephritogenic activity of IgG3 cryoglobulins. Clearly, the identification of the molecular substrate responsible for the nephritogenic activity of IgG3 cryoglobulin $\mathrm{mAb}$ is of paramount importance in understanding molecular and cellular mechanisms responsible for the development of cryoglobulin associated tissue lesions in patients with autoimmune diseases such as SLE, rheumatoid arthritis, and related rheumatic diseases.

\section{Therapeutic approaches of murine monoclonal cryoglobulinaemia}

The experimental model of cryoglobulinaemia associated with vascular and glomerular disease, described above, provides an excellent opportunity to evaluate various therapeutic approaches based on interference at different levels of the essential pathogenic pathways. One of the approaches we undertook was to investigate the possibility of modulating, with a monoclonal anti-idiotypic (anti-Id) antibody, the development of cryoglobulinaemia and tissue lesions induced by the 6-19 $\mathrm{mAb} .{ }^{33}$ The cryoprecipitation of the 6-19 $\mathrm{mAb}$ in vitro was completely and specifically inhibited in the presence of an excess of an anti-Id mAb specific for the 6-19 $\mathrm{mAb}$. One may postulate, to explain this inhibitory phenomenon, that a modification of the electrostatic equilibrium of the $6-19 \mathrm{mAb}$ due to interaction with the antiId $\mathrm{mAb}$ is responsible for the inhibition of 6-19 cryoprecipitation, as in the case of inhibitory activity of charged hapten molecules on cryoprecipitation of $\operatorname{IgG} 3$ anti-hapten $\mathrm{mAb} .{ }^{18}$
Alternatively, modification of the spatial conformation of antibodies by the binding of anti-idiotype, as shown by electron microscopy, ${ }^{34}$ may weaken non-specific IgG3 self association, thereby inhibiting the subsequent cryoglobulin formation.

Strikingly, pretreatment of mice with the anti-Id $\mathrm{mAb}$ completely protected them against the development of cryoglobulin associated skin and glomerular lesions induced by the IgG3 6-19 RF mAb (table 4). As shown by markedly reduced levels of circulating IgG3 6-19 $\mathrm{mAb}$ and increased uptake of 6-19 mAb by the liver in anti-Id pretreated mice in comparison with control mice, ${ }^{33}$ an enhanced clearance of IgG3 6-19 mAb, as a result of Idanti-Id complex formation, seems to be the major mechanism of protection. Moreover, inhibition of the 6-19 mAb cryoprecipitation in the presence of a large excess of anti-Id mAb might also contribute to protection in vivo. Our results suggest that the therapeutic approach with anti-Id $\mathrm{mAb}$ might be successful in similar vascular diseases in man. This might be considered in the future using anti-Id antibodies against the monoclonal component of cryoglobulins. Such antibodies could efficiently eliminate not only the monoclonal component from the circulating blood, but also idiotype positive $B$ cells, as shown in the treatment of B cell lymphomas. ${ }^{35} 36$

In addition to the anti-Id approach, we explored the possibility that non-cryogenerating IgG3 $\mathrm{mAb}$ might inhibit IgG3 cryoglobulin formation as a result of nonspecific interaction between cryoprecipitating and non-cryoprecipitating IgG3 antibodies, and thus inhibit the development of the tissue lesions induced by the IgG3 RF monoclonal cryoglobulin. ${ }^{22}$ In fact, excess amounts of noncryogenerating IgG3 $\mathrm{mAb}$, including 2-6D antinuclear autoantibody, did inhibit the cryoprecipitation of cryogenerating IgG3 mAb, and pretreatment with non-cryogenerating IgG3 $\mathrm{mAb}$ prevented the development of tissue lesions induced by the 6-19 RF monoclonal cryoglobulin. The lack of inhibitory effect by $F\left(a b^{\prime}\right)_{2}$ fragments of noncryoprecipitating mAbs clearly indicates that the observed inhibition was not caused by a specific immunological interaction between cryogenerating and non-cryogenerating IgG3 mAbs. It is likely that because molecules of cryogenerating and non-cryogenerating IgG3 can associate with each other, either in heterologous or homologous aggregates, in a quantitatively similar manner, the physicochemical properties responsible for the cryoglobulin formation of these aggregates would tend to resemble those of the quantitatively dominant IgG3 $\mathrm{mAb}$ in the complex. Accordingly, excess of the noncryogenerating component could result in the inhibition of the cryoprecipitation of the cryogenerating one. It should be also mentioned that in vivo treatment with excess amounts of non-cryogenerating IgG3 $\mathrm{mAb}$ does not interfere with serum levels of 6-19 RF $\mathrm{mAb}$ or its RF activity. This clearly shows that the inhibition of cryoglobulin formation plays 
a central part, and differs from the antiidiotype induced protection, which results mostly from the rapid clearance of 6-19 RF $\mathrm{mAb} .{ }^{33}$

\section{Role of IgG3 cryoglobulins in autoimmune pathology of MRL-lpr/lpr mice}

Demonstration of the pathogenic activity of the cryoprecipitable monoclonal autoantibodies of the IgG3 subclass is significant, because it has long been suggested that cryoglobulins are a potential source of tissue injuries in SLE, rheumatoid arthritis, and related autoimmune diseases. ${ }^{3}$ The generation of 'wire loop' glomerular lesions by IgG3 RF and anti-DNA monoclonal cryoglobulins in the absence of immune complex formation ${ }^{17}$ suggests that autoantibodies with cryoglobulin activity, independently of their immunological specificities, might participate in the pathogenesis of lupus nephritis. In addition to the results obtained with mAbs, several facts support the pathogenic importance of autoantibodies of the IgG3 subclass in murine SLE. Firstly, recent studies on MRL-lpr/lpr and MRL-lpr/lpr $\times($ MRL-lpr/lpr $\times$ C $3 \mathrm{H}-\mathrm{lpr} / \mathrm{lpr})$ backcross mice have shown a good correlation of $\mathrm{IgG} 3$ production with the development of lupus nephritis, and selective enrichment of IgG3 in renal eluates from diseased kidneys. ${ }^{37}$ More recently, we noted that in a new substrain of MRL-lpr/lpr mice, which develops only mild glomerular lesions, the production of cryoglobulins was markedly limited, whereas overall production of autoantibodies did not differ significantly from that of conventional MRL-lpr/lpr mice. ${ }^{37 a}$ Secondly, the transfer of
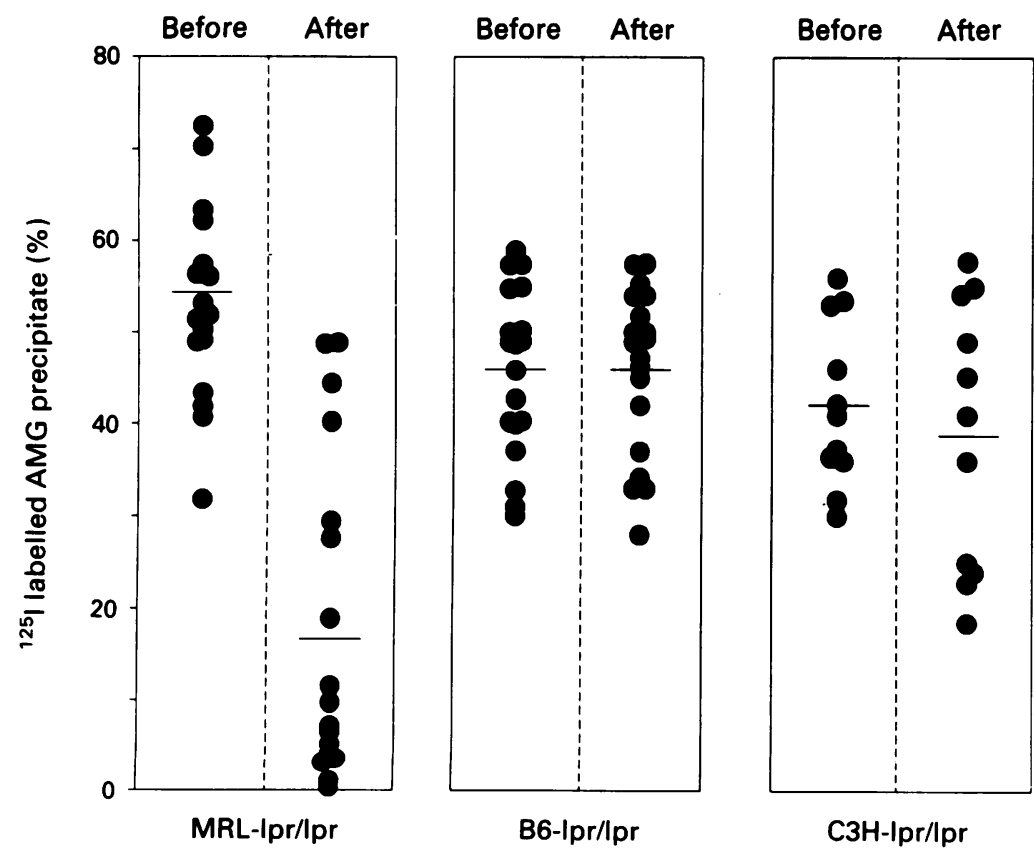

Figure 3 Comparison of serum rheumatoid factor $(R F)$ activities before and after removal of cryoglobulins in three different strains of mice bearing the lpr mutation. $10 \mu$ l of whole serum or serum depleted of cryoglobulins was incubated with $1 \mu \mathrm{g}$ of ${ }^{125}$ I labelled aggregated mouse IgG (AMG) at $4^{\circ} \mathrm{C}$ overnight. ${ }^{125}$ I labelled $A M G$ bound to $R F$ was precipitated and washed three times with phosphate buffered saline by centrifugation at $5000 \mathrm{rpm}$ for five minutes in a microfuge. Results are expressed as percentage precipitation of ${ }^{125}$ I labelled $A M G$. The mean values are indicated by the horizontal line. Adapted from reference 42. the xid ( $\mathrm{X}$ chromosome linked immune deficiency) gene, which causes a defect of IgM and IgG3 production, delayed the development of lupus nephritis in three different lupus-prone mice, including MRLlpr/lpr mice. ${ }^{38-40}$ Finally, the role of cryoglobulins in the generation of joint lesions in MRL-lpr/lpr mice has been recently suggested. ${ }^{41}$ As shown above, however, it should be emphasised that some IgG3 autoantibodies, lacking cryoglobulin activity, can inhibit the development of IgG3 cryoglobulin associated tissue lesions. ${ }^{22}$ This indicates that the balance of formation of IgG3 autoantibodies with or without the cryoglobulin activity may be critical for the development of IgG3 cryoglobulin mediated tissue lesions. In this regard, it should be mentioned that spontaneous production of IgG3 RF with cryoglobulin activity was found in most serum samples from lupus prone MRL-lpr/lpr mice, but rarely in C57BL/6- and C3H-lpr/lpr mice (fig 3). ${ }^{42}$ The lack of production of cryoprecipitable autoantibodies with immunopathological consequences may partly explain the development of only limited autoimmune disease in $\mathrm{C} 57 \mathrm{BL} / 6$ and $\mathrm{C} 3 \mathrm{H}$ mice bearing the lpr mutation. ${ }^{15}$

In view of the pathogenic importance of IgG3 cryoglobulins in murine autoimmune rheumatic diseases, it should be mentioned that human IgG3 have physicochemical properties similar to those of murine IgG3. All the human IgG3 myeloma proteins studied undergo a concentration and temperature dependent aggregation, though not always cryoprecipitation. ${ }^{43-46}$ As this aggregating site seems to be localised in the Fd fragment of the IgG3 heavy chain, ${ }^{43}$ the molecular mechanism of the self association may not be identical in human and murine IgG3. Nevertheless, such a physicochemical property of human IgG3 would explain the frequent enrichment of IgG3 subclass in association with IgM RF in human mixed cryoglobulins. ${ }^{47}$ Although one should be aware of the fact that the qualitative aspect of cryoglobulins may be critically important for expression of their pathogenic activities, the presence of cryoprecipitable autoantibodies should be reassessed in relation to clinical manifestations to determine whether cryoprecipitable autoantibodies are useful and predictive markers of human rheumatic diseases.

The studies from the authors' laboratory discussed in this review were supported by a grant No $31-28782.90$ from the Swiss National Foundation for Scientific Research.

1 Lerner A B, Barnum C P, Watson C J. Studies of cryoglobulins. II. Spontaneous precipitation of protein from serum at $5^{\circ} \mathrm{C}$ in various disease states. $A m \mathcal{F} M e d$ Sci 1947; 214: 416-21.

2 Grey H M, Kohler P F. Cryoimmunoglobulins. Semin Hematol 1973; 10: 87-112.

3 Brouet J C, Clauvel J P, Danon F, Klein M, Seligmann M. Biological and clinical significance of cryoglobulins. $\mathrm{Am}$ Biological and clinical sign

4 Geltner D, Franklin E C, Frangione B. Antiidiotypic activity in the IgM fractions of mixed cryoglobulins. F Immunol in the IgM fractions

5 Reeves W H, Chiorazzi N. Interaction between anti-DNA and anti-DNA-binding protein autoantibodies in cryoglobulins from sera of patients with systemic lupus erythematosus. F Exp Med 1986; 164: 1029-42. 
6 Stone G C, Nardella F A, Oppliger I R, Mannik M. Absence of auto-antiidiotypic activity between the $\operatorname{IgM}$ and $\mathrm{IgG}$ fractions of human mixed cryoglobulins. F Immunol 1988; 140: 3114-9.

7 Middaugh C R, Gerber-Jenson B, Hurvitz A, Paluszek A, Scheffel C, Litman G W. Physicochemical characterization of six monoclonal cryoimmunoglobulins: possible basis for cold-dependent insolubility. Proc Natl Acad Sci USA 1978; 75: 3440-4

8 Middaugh $\mathrm{C} R$, Lawson $\mathrm{E}$ Q, Litman $\mathrm{G} W$, Tisel W A, Mood D A, Rosenberg A. Thermodynamic basis for the abnormal solubility of monoclonal cryoimmunoglobulins. f Biol Chem 1980; 255 : 6532-4.

9 Scoville C D, Turner, D H, Lippert J L, Abraham G N. Study of the kinetic and structural properties of a monoclonal immunoglobulin $\mathrm{G}$ cryoglobulin. 7 Biol Chem 1980; 255: 5847-52

10 Tsai C M, Zopf D A, Yu R K, Wistar Jr R, Ginsburg V. A Waldenström macroglobulin that is both a cold agglutinin and a cryoglobulin because it binds $N$-acetylneuraminosyl residues. Proc Natl Acad Sci USA 1977; 74: 4591-4.

11 Weber R J, Clem L W. The molecular mechanism of cryoprecipitation and cold agglutination of an $\operatorname{Ig} M \lambda$ Waldenström macroglobulin with anti-Gd specificity: sedimentation analysis and localization of interacting sedimentation analysis and loca
sites. F Immunol 1981; 127: 300-5.

12 Patel R D, Brown J C. Preparation and characterization of murine monoclonal antibodies that express both cold agglutinin and cryoglobulin activities. F Immunol 1985; 134: $4041-7$

13 Andrews B S, Eisenberg R A, Theofilopoulos A N, et al. Spontaneous murine lupus-like syndromes. Clinical and immunopathological manifestations in several strains. $f$ Exp Med 1978; 148: 1198-215.

14 Abdelmoula M, Spertini F, Shibata T, et al. IgG3 is the major source of cryoglobulins in mice. $\mathcal{F}$ Immunol 1989; 143: $526-32$.

15 Izui S, Kelley V E, Masuda K, Yoshida H, Roths I B, Murphy E D. Induction of various autoantibodies by mutant gene lpr in several strains of mice. $\mathcal{f}$ Immunol mutant gene $1 \mathrm{pr}$ in

16 Gyotoku Y, Abdelmoula M, Spertini F, Izui S, Lambert P $\mathrm{H}$. Cryoglobulinemia induced by monoclonal IgG rheumatoid factors derived from autoimmune MRL/MpJlpr/lpr mice. F Immunol 1987; 138: 3785-92.

17 Lemoine R, Berney T, Shibata T, et al. Induction of "wireloop" lesions by murine monoclonal IgG3 cryoglobulins. Kidney Int 1992; 41: 65-72.

18 Spertini F, Coulie P G, Van Snick J, Davidson E, Lambert $\mathrm{P}$ H, Izui S. Inhibition of cryoprecipitation of murine IgG3 anti-dinitrophenyl (DNP) monoclonal antibodies IgG3 anti-dinitrophenyl (DNP) monoclonal antibodies
by anionic DNP-amino acid conjugates. Eur $\mathcal{f}$ Immunol by anionic DNP

19 Schluesener H, Brunner C, Vass K, Lassmann H. Therapy of rat autoimmune disease by a monoclonal antibody specific for $\mathrm{T}$ lymphoblasts. $\mathcal{F}$ Immunol 1986; 137: 3814-20.

20 Depinho R A, Feldman L B, Scharff M D. Tailor-made monoclonal antibodies. Ann Intern Med 1986; 104: 225-33.

21 Takahashi $S$, Itoh $J$, Ono $M$, Yamamoto $T$, Nose $M$, Kyogoku M. cDNA sequence analysis of nephritogenic IgG3 monoclonal antibodies derived from an MRL/pr lupus mouse. Mol Immunol. In press.

21 aFulpius T, Spertini F, Reininger L, Izui S. Immunoglobulin heavy chain constant region determines the pathogenicity
and the antigen-binding activity of rheumatoid factor. and the antigen-binding activity
Proc Natl Acad Sci USA. In press.

22 Berney T, Shibata T, Izui S. Murine cryoglobulinemia: pathogenic and protective IgG3 self-associating antibodies. F Immunol 1991; 147: 3331-5.

23 Grey $\mathrm{H}$ M, Hirst J W, Cohn M. A new mouse immunoglobulin: IgG3. 7 Exp Med 1971; 133: 289-304

24 Berney $\mathrm{T}$, Fulpius $\mathrm{T}$, Shibata $\mathrm{T}$, et al. Selective pathogenicity of murine rheumatoid factors of the cryoprecipitable IgG3 subclass. Int Immunol 1992; 4: 93-9.

25 Lawson E Q, Brandau D T, Trautman P A, Middaugh C R. Electrostatic properties of cryoimmunoglobulins. $f$ Immunol 1988; 140: 1218-22.

26 Middaugh C R, Litman G W. Atypical glycosylation of an IgG monoclonal cryoimmunoglobulin. f Biol Chem 1987 262: $3671-3$
27 Lawson E Q, Hedlund B E, Ericson M E, Mood D A, Litman G W, Middaugh R. Effect of carbohydrate on protein solubility. Arch Biochem Biophys 1983; 220 $572-5$

28 Wels J A, Word C J, Rimm D, et al. Structural analysis of the murine IgG3 constant region gene. EMBO f 1984; 3: 2041-6.

29 Kang C Y, Brunck T K, Kieber-Emmons T, Blalock J E, Kohler $\mathrm{H}$. Inhibition of self-binding antibodies (autobodies) by a VH-derived peptide. Science 1988; 240 (autobodies.

30 Reininger L, Berney T, Shibata T, Spertini F, Merino R Izui $S$. Cryoglobulinemia induced by a murine IgG3 rheumatoid factor: skin vasculitis and glomerulonephritis arise from distinct pathogenic mechanisms. Proc Nat Acad Sci USA 1990; 87: 10038-42.

31 Verroust P, Morel-Maroger L, Preud'homme J L. Renal lesions in dysproteinemias. Springer Semin Immunopathol 1982; 5: 333-56.

32 Shlomchik $M$, Mascelli $M$, Shan $H$, et al. Anti-DNA antibodies from autoimmune mice arise by clonal expansion and somatic mutation. F Exp Med 1990; 171: 265-92.

33 Spertini F, Donati Y, Welle I, Izui S, Lambert P H Prevention of murine cryoglobulinemia and associated pathology by monoclonal anti-idiotypic antibody. $f$ Immunol 1989; 143: 2508-13.

34 Roux K H, Monafo W J, Davie J M, Greenspan N S. Construction of an extended three-dimentional idiotype map by electron microscopic analysis of idiotope-antiidiotope complexes. Proc Natl Acad Sci USA 1987; 84: 4984-8.

35 Krolick K A, Uhr J W, Slavin S, Vitetta E S. In vivo therapy of a murine $\mathrm{B}$ cell tumor $\left(\mathrm{BCL}_{1}\right)$ using antibody-ricin $A$ chain immunotoxins. $\mathcal{F}$ Exp Med 1982; 155: 1797-809.

36 Miller R A, Maloney D G, Warnke R, Levy R. Treatmen of B-cell lymphoma with monoclonal anti-idiotype antibody. $N$ Engl f Med 1982; 306: 517-22

37aFossati L, Takahashi S, Merino R, et al. An MRL/MpJ-lpr/ lpr substrain with a limited expansion of lpr double negative $T$ cells and a reduced autoimmune syndrome. International Immunology. In press.

37 Takahashi S, Nose M, Sasaki J, Yamamoto T, Kyogoku M $\mathrm{IgG} 3$ production in MRL/pr mice is responsible fo development of lupus nephritis. F Immunol 1991; 147: $515-9$

38 Steinberg B J, Smathers P A, Frederiksen K, Steinberg A $D$. Ability of the xid gene to prevent autoimmunity in $(\mathrm{NZB} \times \mathrm{NZW}) \mathrm{F}$, mice during the course of their natural history, after polyclonal stimulation, or following

39 Smith H R, Chused T M, Steinberg A D. The effect of the $\mathrm{X}$-linked immune deficiency gene (xid) upon the $\mathrm{Y}$ chromosome-related disease of BXSB mice. $f$ Immunol 1983; 131: 1257-62.

40 Steinberg E B, Santoro T J, Chused T M, Smathers P A Steinberg A D. Studies of congenic MRL-lpr/lpr.xid mice. f Immunol 1983; 131: 2789-95.

41 Itoh J, Nose $M$, Kyogoku M. Pathogenic significance of serum components in the development of autoimmune polvarthritis in MRL/Mp mice bearing the lymphoproliferation gene. Am f Pathol 1991; 139: 511-21.

42 Shibata T, Berney T, Spertini F, Izui S. Rheumatoid factors (RF) in mice bearing the lpr or gld mutation. Selective production of RF cryoglobulins in MRL/MpJ-lpr/lpr production of RF cryoglobulins in $\mathrm{MR}$

43 Capra J D, Kunkel H G. Aggregation of $\gamma \mathrm{G} 3$ proteins: relevance to the hyperviscosity syndrome. $\mathcal{f}$ Clin Invest 1970; 49:610-21.

44 Grey H M, Kohler P F, Terry W D, Franklin E C. Human monoclonal $\gamma \mathrm{G}$-cryoglobulins with anti- $\gamma$-globulin activity. $\mathcal{F}$ Clin Invest 1968; 47: 1875-84.

45 Saluk P H, Clem W. Studies on the cryoprecipitation of a human IgG3 cryoglobulin: the effects of temperatureinduced conformational changes on the primary interaction. Immunochemistry 1975;12: 29-37.

46 Nishimura Y, Nakamura H. Human monoclonal cryoimmunoglobulins. I. Molecular properties of IgG3k (Jir protein) and the cryo-coprecipitability of its molecular (Jir protein) and the cryo-coprecipitability of its mo

47 Cream J J, Howard A, Virella G. IgG heavy chain subclasses in mixed cryoglobulins. Immunology 1972; 23: classes in 